\title{
Guest editorial: Grand successes and failures in IT: Private and public sectors
}

\author{
Yogesh K. Dwivedi • David Wastell • \\ Helle Zinner Henriksen • Rahul De'
}

Published online: 16 January 2015

(C) Springer Science+Business Media New York 2015

The recent abandonment of a multi-billion dollar project in the UK to computerize health records ${ }^{1}$ provides testimony that knowledge accumulated in the MIS field has failed to impact successfully on policy and practice. The larger the scale of such IS implementations, the higher, it appears, is the risk. Implementation of organisation wide systems (for example, ERP), automated supply chain management enabled by Interorganisational systems (IOS), emerging technologies (such as Cloud computing) add further complexity both at the project and system level, thereby augmenting the risk of failure. Other recent examples of major failure in both public and private sector include: Sainsbury's failed automated logistics system, ${ }^{2}$ the much-publicised software problems of the Toyota Prius, ${ }^{3}$ and the UK Government's abandonment of national ID cards. ${ }^{4}$

\footnotetext{
${ }^{1} \mathrm{http}: / / \mathrm{www} \cdot$ huffingtonpost.com/stephen-soumerai/dont-repeat-the-ukselect_b_790470.html

${ }^{2} \mathrm{http}: / /$ www.theregister.co.uk/2004/10/19/sainsburys_v_accenture/

$3 \mathrm{http} / / /$ articles.latimes.com/2014/feb/12/autos/la-fi-hy-toyota-priusrecall-20140212

${ }^{4}$ http://www.bbc.co.uk/news/10164331
}

Y. K. Dwivedi $(\square)$

School of Management, Haldane Building, Swansea University, Singleton Park, Swansea SA2 8PP, Wales, UK

e-mail: y.k.dwivedi@swansea.ac.uk

\section{Wastell}

Operations Management and Information Systems, Nottingham University Business School, Jubilee Campus, Nottingham, UK e-mail: David.Wastell@nottingham.ac.uk

\section{H. Z. Henriksen}

Department of IT Management (ITM), Copenhagen Business

School, Frederiksberg, Denmark

e-mail: hzh.itm@cbs.dk

R. De'

Indian Institute of Management Bangalore (IIMB), Bengaluru, India

e-mail: rahul@iimb.ernet.in
Technology enabled global practices (such as outsourcing) have also fundamentally changed the way that IS/IT is developed. Such practices have advantages but in themselves bring new risks, which can lead to failure, causing significant economic loss to the organisations.

Such high profile failures show that, despite decades of research and the accumulation of a substantial knowledgebase within MIS (see for example, Avison and Wilson 2002; Barker and Frolick 2003; Beynon-Davies 1995;1996; Bussen and Myers 1997; Cerpa and Verner 2009; Dwivedi et al. 2013a; Fitzgerald and Russo 2005; Heeks 2002; Kappelman et al. 2006; Lyytinen and Hirschheim 1988; McMaster and Wastell 2004; Nelson 2007; Sauer 1993; Yeo 2002), further progress is required to improve the conduct of information systems initiatives. Faced with this, it is pertinent to ask why our scholarship has not been more effective. Is the fault one of theory and inadequate understanding? Or is the problem one of knowledge transfer, the failure to embed research knowledge in the working practices of managers and policy-makers. This special issue aims to move forward our understanding of the success and failure of information and communication technology-based innovation, and on the factors influencing the uptake of research knowledge in the practitioner community. The accepted papers are briefly summarised below.

Janssen et al.'s article (Failure of Large Transformation Projects from the Viewpoint of Complex Adaptive Systems: Management Principles for Dealing with Project Dynamics) adopted a complex adaptive system (CAS) in order to understand better project dynamics and identify management principles for dealing with them. A case study of a large transformation project in the Netherlands was carried out, in which seven patterns were found through which project dynamics could be identified. A logical consequence of the immense complexity of the case study was that stakeholders lost sight of the overall goals, and instead focused on managing short-term 
incidents and approached the project in an ad hoc way. Informed by CAS theory, this study presented eight management principles that address the complexities of this type of project and can aid in coping with project dynamics (Janssen et al. 2015).

The article by Rao and De' entitled Technology assimilation through conjunctures - a look at IS use in retail attempted to examine the assimilation of IT by an organization establishing itself in the emerging Indian retail industry. The study applied strong structuration theory, which is a refinement of Giddens' structuration theory, as the theoretical lens for studying the technology assimilation process. This was integrated with elements from actor network theory to incorporate socio-technical perspectives. The study analysed the assimilation process as a series of conjunctures, and illustrates how socio-technical changes, situated actions and the conjuncture's context influence the assimilation process (Rao and De' 2015).

Bunker et al.'s article (Repertoires of Collaboration for Common Operating Pictures of Disasters and Extreme Events) argued that disasters are dynamic, emergent scenarios involving diverse stakeholders in complex decision making and as such, disaster response systems must account for these conditions. The study suggested that emergency service agencies should consider supplementing their traditional command and control approaches and common operating pictures (COP), with purposeful collaborative approaches. This research utilized McCann's model of Social Problem Solving Negotiated Arrangements (SPS-NA) to highlight problems with conventional approaches during three disaster scenarios. Based on data-sources from three internationally well-known large-scale disasters the authors analyse the strength of the framework. As a result of lessons learned, the study recommends that developing supplementary repertoires of collaboration would have a positive impact on improved COP for effective disaster response outcomes (Bunker et al. 2015).

Madsen et al.'s article (Knowledge Transfer Planning and Execution in Offshore Outsourcing: An Applied Approach) reported a longitudinal project about knowledge transfer conducted in a major financial company headquartered in Denmark and an offshore development center located in Bangalore, India. The study identified the main knowledge transfer challenges experienced by the case company, which informed the conceptual design of a systematic five-step approach to the company's knowledge transfer. The study drew attention to the fact that client side managers play a crucial role in determining how, and with what priority, knowledge transfer can take place. This article also suggests that a first, important step towards ensuring successful knowledge transfer in outsourcing is to focus on the training and support of client side managers (Madsen et al. 2015).

Brooks and Alam's paper Designing an information system for updating land records in Bangladesh, reflects on applying Action Design Research (ADR) in a complex organizational context in a developing country. The study showed that ADR requires additional theory for designing IS in such a complex organizational context. Through conducting ADR, it is seen that an ethnographic framework has potential complementarities for understanding complex contexts thereby enhancing the ADR process. This paper argued that conducting ADR with an ethnographic approach enhances the design of IS. This paper aimed also to present a broader methodological framework, Action Design Ethnographic Research (ADER), for designing artefacts as well as IS, which is illustrated through the case of a land records updating service in Bangladesh (Brooks and Alam 2015).

Elbanna and Linderoth's contribution focused on The Formation of Technology Mental Models in Voluntary Use Organizational Settings. This study questions why and how users choose to engage (or not) with open technology on a voluntary basis and how and why its use options and potential unfold? The study examined a longitudinal case study (1994-2012) on the voluntary use of telemedicine. The findings revealed that users' perception of open technology in a voluntary setting is formed through a continuous interplay between users' mental models of technology, professional identity, institutional traditions and arrangements and work practices. If contradictions arise in this interplay, users' mental models can be fixated on the misfit, and the misfit is thereby reinforced. Hence, users do not try to develop use-cases or think of possible applications. However, institutional entrepreneurs could break this self-fulfilling prophecy by influencing both the mental models of users and the institutional arrangements (Elbanna and Linderoth 2015).

Hossain and Quaddus (Developing and validating a hierarchical model of external responsiveness: A study on RFID technology) employed both qualitative and quantitative approaches to develop and validate a multi-dimensional hierarchical model of external responsiveness and its effect on adoption intention. The findings of the study show that in the context of Radio Frequency Identification (RFID) technology, external responsiveness is a third-order, reflective construct which is influenced by external pressure (government pressure, market pressure, mimetic pressure, and normative pressure), external support (government support, vendor support, and associative support), and external uncertainty (market and technology uncertainty). Moreover, the impact of the third-order and second-order constructs on the intention to adopt RFID is examined, and found to have positive influences (Hossain and Quaddus 2015).

Rana et al. examined the success of an online public grievance redress system (OPGRS) from the perspective of the citizens of India. The success of this e-government system is examined using an integrated IS success model, which was validated using the response collected from 419 citizens from different cities of India. The empirical outcomes provided 
support for the hypothesised relationships between eight constructs (Rana et al. 2015).

In addition to regular submissions, a panel of IFIP 8.6 2013 participants were invited to develop a perspective-oriented and direction-setting paper on the theme of IS success and failure. This multi-authored paper by Dwivedi, Wastell, Laumer, Henriksen, Myers, Bunker, Elbanna, Ravishankar and Srivastava is entitled Research on Information Systems Failures and Successes: Status Update and Future Directions. The article produced by the Panel aimed to reflect on the need for new perspectives and research directions to provide insights and further guidance for managers on factors enabling IS success and for avoiding IS failure. Several key issues emerged, such as the need to study problems from multiple perspectives, to move beyond narrow considerations of the IT artifact, and to venture into underexplored organizational contexts, such as the public sector (Dwivedi et al. 2015).

This special issue has evolved from research presented during the 14th IFIP WG 8.6 Conference ${ }^{5}$ which was hosted at the Indian Institute Management Bangalore, India in June 2013. The conference invited the following two types of submissions: full-length journal style papers and short papers, which could be research in progress or polemical "position papers". The call for papers attracted 65 submissions, representing a broad international cross-section of authors. These submissions were reviewed rigorously by two independent reviewers which resulted in selection of the final set of 35 full papers that appeared in the blind peer-review conference proceedings. Accepted submissions were clustered into the following five categories. Ten accepted submissions addressed the conference theme of IS success/failure. Nine papers examined IT in the public sector, which was followed by a set of seven papers that addressed more general aspects of IS theory and methodology. Five studies focused on the adoption or acceptance of IT. Finally, software development related issues were addressed by four papers. Further detail about content of the conference proceedings can be found in Dwivedi et al. (2013b).

Eight papers (from the 35 conference articles) were selected for consideration for publication in this special issue of Information Systems Frontiers. The following guidelines were used for selection of these articles. We identified a set of papers with substantial empirical content and theoretical contribution that represented the range of issues bearing on the conference theme. The results of the peer-review process for the conference influenced our selection decisions, enabling the co-editors of this special issue individually to identify and rank a set of eight papers. The short-lists prepared by each coeditor were then correlated to identify eight papers that were ranked favourably by all four co-editors. Guest editors' recommendations were then communicated to the chief editors of

\footnotetext{
${ }^{5}$ http://ifipwg86.wikidot.com/publications
}

the journal. Initially, authors of shortlisted papers were provided with feedback outlining suggestions for improving and extending their papers. The revised and substantially extended versions were submitted online, and each submission went through three rounds of further reviews involving three reviewers each (Appendix).

Acknowledgments We would like to thank the Chief Editors 'Prof. H. Raghav Rao and Prof. Ram Ramesh' of the Information Systems Frontiers for providing the opportunity to organize this special issue. The guest editors also gratefully acknowledge the support of referees who reviewed the manuscripts submitted for possible publication in this special issue.

\section{Appendix: List of referees}

Keld Bødker, Roskilde University, Denmark

Deborah Bunker, The University of Sydney, Australia

Laurence Brooks, Brunel University, UK

Rahul De', Indian Institute of Management Bangalore, India

Yogesh K. Dwivedi, Swansea University, UK

Amany Elbanna, Royal Holloway, UK

Helle Zinner Henriksen, Copenhagen Business School, Denmark

Mohammad Alamgir Hossain, North South University, Bangladesh

Marijn Janssen, Delft University of Technology, Netherlands

Linda Levine, Independent Researcher Consultant, USA

Nripendra P Rana, Swansea University, UK

Ravi Anand Rao, Indian Institute of Management Bangalore, India

Dave Wastell, Nottingham University Business School, UK

\section{References}

Avison, D., \& Wilson, D. (2002). IT failure and the collapse of One. Tel. In Information Systems: Springer, pp. 31-46.

Barker, T., \& Frolick, M. N. (2003). ERP implementation failure: a case study. Information Systems Management, 20(4), 43-49.

Beynon-Davies, P. (1995). Information systems 'failure': the case of the London Ambulance Service's Computer Aided Despatch project. European Journal of Information Systems, 4(3), 171-184.

Brooks, L., \& Alam, M. S. (2015). Designing an information system for updating land records in Bangladesh: Action design ethnographic research (ADER). Information Systems Frontiers, 17(1). doi: 10.1007/s10796-014-9512-7.

Bunker, D., Levine, L., \& Woody, C. (2015). Repertoires of collaboration for common operating pictures of disasters and extreme events. Information Systems Frontiers, 17(1). doi:10.1007/s10796-014-9515-4.

Bussen, W., \& Myers, M. D. (1997). Executive information system failure: a New Zealand case study. Journal of Information Technology, 12(2), 145-153.

Cerpa, N., \& Verner, J. M. (2009). Why did your project fail? Communications of the ACM, 52(12), 130-134.

Dwivedi, Y. K., Ravichandran, K., Williams, M. D., Miller, S., Lal, B., Antony, G. V., \& Kartik, M. (2013a). IS/IT project failures: A review 
of the extant literature for deriving a taxonomy of failure factors. In Y. K. Dwivedi, H. Z. Henriksen, D. Wastell, \& R. De (Eds.), Grand successes and failures in IT. Public and private sectors (pp. 73-88). Berlin: Springer.

Dwivedi, Y.K., Henriksen, H.Z., Wastell, D., \& De', R. (eds.). (2013b). Grand Successes and Failures in IT: Public and Private Sectors. Springer.

Dwivedi, Y. K., Wastell, D., Laumer, S., Henriksen, H. Z., Myers, M. D., Bunker, D., Elbanna, A., Ravishankar, M.N., \& Srivastava, S. C. (2015). Research on information systems failures and successes: Status update and future directions. Information Systems Frontiers, 17(1). doi:10.1007/s10796-014-9500-y.

Elbanna, A., \& Linderoth, H. C. J. (2015). The formation of technology mental models: the case of voluntary use of technology in organizational setting. Information Systems Frontiers, 17(1). doi:10.1007/ s10796-014-9513-6.

Fitzgerald, G., \& Russo, N. L. (2005). The turnaround of the London ambulance service computer-aided despatch system (LASCAD). European Journal of Information Systems, 14(3), 244-257.

Heeks, R. (2002). Information systems and developing countries: failure, success, and local improvisations. The Information Society, 18(2), $101-112$.

Hossain, M. A., \& Quaddus, M. (2015). Developing and validating a hierarchical model of external responsiveness: A study on RFID technology. Information Systems Frontiers, 17(1). doi:10.1007/ s10796-014-9503-8.

Janssen, M., van der Voort, H., \& van Veenstra, A. F. (2015). Failure of large transformation projects from the viewpoint of complex adaptive systems: Management principles for dealing with project dynamics. Information Systems Frontiers, 17(1). doi:10.1007/s10796014-9511-8.

Kappelman, L. A., McKeeman, R., \& Zhang, L. (2006). Early warning signs of IT project failure: the dominant dozen. Information Systems Management, 23(4), 31-36.

Lyytinen, K., \& Hirschheim, R. (1988). Information systems failures - a survey and classification of the empirical literature. In Oxford surveys in information technology, pp. 257-309.

Madsen, S., Bødker, K., \& Tøth, T. (2015). Knowledge Transfer Planning and Execution in Offshore Outsourcing: An Applied Approach. Information Systems Frontiers, 17(1). doi:10.1007/s10796-0149516-3.

McMaster, T., \& Wastell, D.(2004)., "Success and Failure Revisited in the Implementation of New Technology: Some Reflections on the Capella Project", in Innovation for Adaptability and Competitiveness, Proceedings of IFIP WG8.6 Working Conference, Leixlip, Ireland, Boston, Kulwer.

Nelson, R. R. (2007). IT project management: infamous failures, classic mistakes, and best practices. MIS Quarterly Executive, 6(2), 67-78.

Rana, N. P., Dwivedi, Y. K., Williams, M. D., \& Weerakkody, V. (2015). Investigating success of an e-government initiative: Validation of an integrated IS success model. Information Systems Frontiers, 17(1). doi: 10.1007/s10796-014-9504-7.

Rao, R. A. and De', R. (2015). Technology assimilation through conjunctures-a look at IS use in retail. Information Systems Frontiers, 17(1). doi: 10.1007/s10796-014-9510-9.

Sauer, C. (1993). Why information systems fail: a case study approach: Alfred Waller Ltd., Publishers.

Yeo, K. T. (2002). Critical failure factors in information system projects. International Journal of Project Management, 20(3), 241-246.

Yogesh K. Dwivedi is Professor of Digital and Social Media at the School of Management, Swansea University, Wales, UK. He obtained his $\mathrm{PhD}$ and MSc in Information Systems from Brunel University, UK. He has co-authored several papers which have appeared in international referred journals such as CACM, DATA BASE, EJIS, ISJ, ISF, JCIS, JIT, JORS, and IMDS. He is Associate Editor of European Journal of Information Systems, Assistant Editor of TGPPP, Managing Editor of JECR and member of the editorial board/review board of several journals. He is a member of the AIS and IFIP WG8.6.

David Wastell is Professor of Information Systems at Nottingham University Business School. His current interests are in public sector reform, neuroscience and social policy, technological innovation and cognitive ergonomics. David's ideas about design and the managerial role are set out in a book published in 2011, entitled: Managers as designers in the public services: beyond technomagic. He is currently President Elect of the UK Academy of Information System and vice Chair of IFIP WG8.6.

Helle Zinner Henriksen is associate professor in IT in public sector at Department of IT Management at Copenhagen Business School. Her research interests include eGovernment with particular focus on adoption and diffusion of IT innovations in the public sector including the understanding of institutional instruments stimulating adoption and diffusion of IT. HZH has published in some of the leading eGovernment journals such as Government Information Quarterly, The Electronic Journal of eGovernment and International Journal of Electronic Government Research and in IS journals such as the EJIS, JSIS, SJIS and JIT.

Rahul De' is the Hewlett-Packard Chair Professor in ICT for Sustainable Economic Development at IIM Bangalore. His research interests are in ICT for development, economic impact of open source software and evaluation of e-Government systems. He has published over 50 articles in international journals, refereed conference proceedings and as chapters in books, and an MIS textbook. He has won two Outstanding Paper awards for his research and one for teaching, conferred at international conferences 